\title{
PEMBERDAYAAN USAHA TAHU DI DUSUN BANDA DESA SABA KECAMATAN BLAHBATUH GIANYAR
}

\section{EMPOWERMENT OF TOFU BUSINESSES IN BANDA, VILLAGE SABA, BLAHBATUH GIANYAR}

\section{Wayan Hesadijaya Utthavi' ${ }^{1)}$, I Gede Nyoman Suta Waisnawa ${ }^{2)}$, Ni Luh Ayu Kartika Yuniastari Sarja ${ }^{3)^{*}}$, Putu Adi Suprapto ${ }^{4)}$}

\author{
${ }^{1)}$ Akuntansi, Politeknik Negeri Bali, Bali, email: hesadijayau@gmail.com \\ ${ }^{2)}$ Teknik Mesin, Politeknik Negeri Bali, Bali, email: sutawaisnawa@pnb.ac.id \\ ${ }^{3)}$ Pariwisata, Politeknik Negeri Bali, Bali, email: yuniastari@pnb.ac.id \\ ${ }^{4)}$ Akuntansi, Politeknik Negeri Bali, Bali, email: adisuprapto@pnb.ac.id
}

\section{ABSTRAK}

Tahu merupakan salah satu jenis makanan yang dapat dinikmati dan dapat dengan mudah didapatkan oleh semula kalangan masyarakat. Tahu merupakan makanan dengan gizi tinggi. Mitra dalam kegiatan ini adalah Bapak Nyoman Gorim. Mitra memiliki usaha produksi tahu. Bapak Nyoman Gorim berasal dari Dusun Banda Desa Saba, Kecamatan Blahbatuh Kabupaten Gianyar. Pada saat ini, terdapat beberapa kendala berupa keterbatasan dalam alat bantu produksi, kemasan produk tahu, kurangnya manajemen keuangan serta pemasaran produk. Berdasarkan kendala yang dihadapi mitra, dilakukan pemberdayaan usaha tahu melalui kegiatan secara bertahap dari aspek produksi, manajemen dan pemasaran. Metode kegiatan dimulai dengan sosialisasi, pemberian peralatan sebagai alat bantu produksi seperti mesin penggiling bahan baku, pelatihan pengemasan, pelatihan manajemen keuangan, pembuatan sosial media serta pelatihan penggunaan sosial media. Indikator capaian adalah peningkatan $50 \%$ jumlah produksi, $50 \%$ produk berisi label kemasan dengan melibatkan 2 orang karyawan, mitra mempunyai media sosial facebook dan instagram sebagai media pemasaran, 1 orang anggota dapat mengelola pembukuan dan pencatatan keuangan dan 1 orang anggota dapat melakukan pengelolaan terhadap content media sosial. Berdasarkan hasil evaluasi didapatkan bahwa adanya peningkatan jumlah produksi sebanyak $60 \%$, peningkatan pengetahuan mitra mengenai pencatatan keuangan dan pemasaran menggunakan media online, terciptanya produk tahu yang lebih ekslusif dengan kemasan dan label yang baru.

Kata kunci: Tahu, Peralatan Produksi, Manajemen Keuangan, Media Sosial

\section{ABSTRACT}

Tofu is one type of food that can be enjoyed and can be easily obtained by the community at first. Tofu is a high nutrient food. The partner in this activity is Mr. Nyoman Gorim. Partners have a tofu production business. Mr. Nyoman Gorim comes from Banda, Saba Village, Blahbatuh District, Gianyar Regency. At this time, there are several obstacles in the form of limitations in production aids, tofu product packaging, lack of financial management, and product marketing. Based on the obstacles faced by partners, tofu business empowerment was carried out through activities in stages, from the aspects of production, management and, marketing. The activity method starts with socialization, provision of equipment as production aids, packaging training, financial management training, social media creation and, social media usage training. The achievement indicator is an increase in the amount of production by up to 50\%, 50\% of the product contains packaging labels involving 2 employees, partners have social media Facebook and Instagram as marketing media, 1 member can manage financial books and records and 1 member can manage social media content. Based on the results of the evaluation, it was found that there was an increase in the number of production by $60 \%$, an increase in partner knowledge about financial recording and marketing using online media, the creation of more exclusive tofu products with new packaging, and labels.

Keywords: Tofu, Production Equipment, Financial Management, Social Media 
PENDAHULUAN

Tahu merupakan salah satu jenis keunggulan tahu produksi Bapak Nyoman makanan yang dapat dinikmati dan dapat Gorim ini adalah bahan baku kedelai dikupas dengan mudah didapatkan oleh semula sehingga lebih bersih sebelum dilakukan kalangan masyarakat. Tahu menjadi produksi. Dalam proses penyelesaian alternatif kebutuhan pokok bagi masyarakat produksi tahu mitra dibantu oleh 3 orang yang daya belinya terbatas dikarenakan karyawan. Peralatan produksi yang harganya murah [1]. Tahu merupakan digunakan mitra seperti mesin olah kedelai makanan dengan gizi tinggi. Tahu memiliki atau mesin penggiling kedelai, alat cetak gizi yang cukup tinggi dan juga mengandung tahu, alat merebus kedelai, penggorengan, beberapa macam asam amino yang kain untuk memeras, kayu bakar untuk dibutuhkan oleh tubuh manusia [2]. Tahu memasak. Sebagian alat produksi masih juga dapat diolah menjadi aneka makanan. menggunakan alat yang tradisional seperti Tahu diproduksi dengan bahan dasar berupa kain untuk melakukan penyaringan, alat biji kedelai. Pemberdayaan pada UMKM cetak tahu yang terbuat dari kayu. khususnya usaha tahu telah dilakukan seperti Sedangkan mesin olah atau penggiling dalam hal pendidikan kewirausahaan [3][4], kedelai merupakan mesin yang mempunyai perbaikan mutu produksi [5], optimalisasi kapasitas kecil dan sudah berumur sehingga produksi [6], operasional usaha [7] dan proses produksi berjalan lambat. inovasi produk [8].

Mitra tidak mengetahui dengan pasti

Mitra dalam kegiatan ini adalah Bapak jumlah keuntungan atau kerugian. Bapak Nyoman Gorim. Mitra memiliki usaha Nyoman Gorim tidak pernah mencatat produksi tahu. Bapak Nyoman Gorim jumlah pemasukan maupun pengeluran yang berasal dari Dusun Banda Desa Saba. Desa diperoleh, hanya mengumpulkan nota Saba merupakan salah satu desa yang pembelian bahan baku. Pendapatan mitra terdapat pada kecamatan Blahbatuh tidak menentu dipengaruhi oleh banyak Kabupaten Gianyar. Jarak lokasi mitra permintaan dari konsumen dan pesanan dari (Dusun Banda) dengan pengusul kira- konsumen. Penjualan mitra berkisar antara kira37,7 km. Desa Banda dapat dicapai Rp. 450.000 - Rp 700.000. dalam waktu 53 menit dari Jimbaran.

Penjualan dan pemasaran produksi tahu

Mitra Bapak Nyoman Gorim melakukan mitra adalah menjual produk langsung di produksi tahu mulai 1980. Dalam pasar Blahbatuh serta juga menitipkan tahu memproduksi tahu, Bapak Nyoman Gorim ini pada warung-warung yang ada pada mendapatkan bahan baku dari supplier Dusun Banda. Selain itu distribusi dilakukan kacang kedelai yang berada di Klungkung, oleh agen yang mengambil langsung di Bali. 
berdasarkan pesanan dari pelanggan.

Kemasan tahu masih sangat sederhana yaitu membungkusnya dengan kantong plastik.

Bahan baku dalam proses produksi dapat dilihat pada Gambar 1. Dalam proses produksi terlebih dahulu kedelai dibersihkan sehingga siap untuk diolah. Proses pembuatan tahu dilakukan dengan mencuci kedelai yang telah dibersihkan, kemudian kedelai tersebut dipecah menggunakan mesin penggiling kedelai. Setelah hancur, kedelai direbus atau dimasak dengan kayu api menggunakan wajan besar. Hal ini dilakukan agar kematangan kedelai lebih terukur. Setelah masak, bahan tersebut diaduk dalam bak sampai kental. Setelah kental, dibungkus dengan kain untuk menyaring. Kemudian hasil penyaringan dapat diletakkan dalam alat pencetak berupa kayu. Dalam satu alat pencetak dapat menghasilkan kurang lebih 100 pcs tahu. Setelah itu tahu dapat dipotong-potong. Proses produksi tahu kurang lebih sekitar 5 jam.

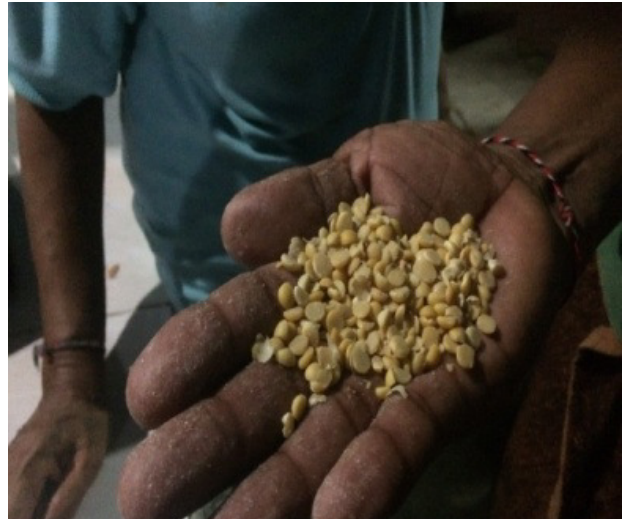

Gambar 1 Bahan baku produksi

Peralatan yang digunakan dalam produksi tahu dapat dilihat pada Gambar 2.

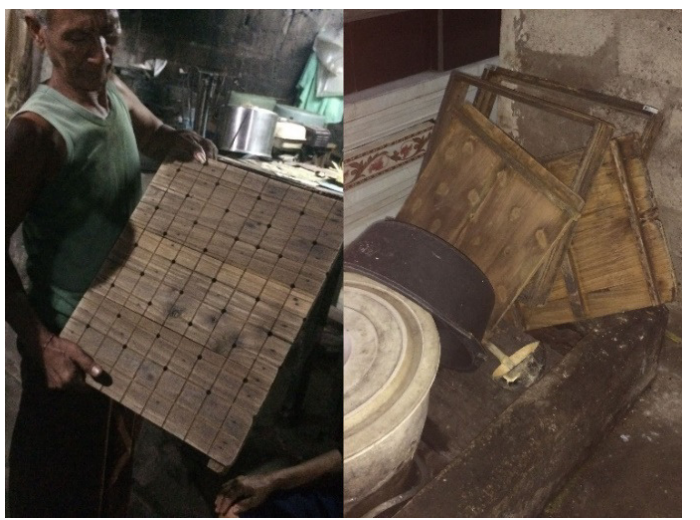

Gambar 2 Alat produksi yang digunakan mitra

Sedangkan produk tahu yang telah siap dipasarkan dapat dilihat pada Gambar 3.

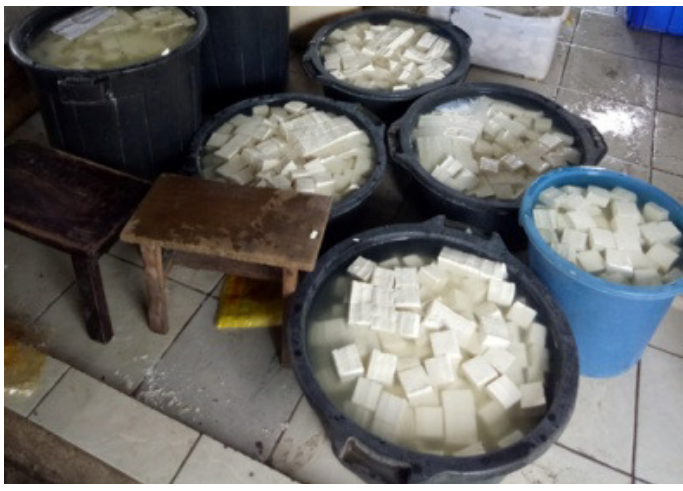

Gambar 3 Produk tahu mitra

Berdasarkan hasil analisa terhadap situasi yang ada pada mitra maka diketahui permasalahan prioritas adalah sebagai berikut:

1. Keterbatasan dalam alat produksi tahu. Kurang efisiennya proses produksi karena hanya menggunakan alat penggiling memiliki kapasitas yang kecil, pencetak manual, wajan yang terbatas dan penyaring manual berupa kain.

2. Produk tahu hanya dikemas menggunakan kantong plastik. Kemasan produk tidak memiliki desain atau ciri khas mitra sehingga tidak ada informasi mengenai mitra. 
3. Pemasaran produk saat ini masih Peserta adalah pemilik dan pegawai pada konvensional yaitu secara langsung di UKM yang menjadi mitra dalam kegiatan pasar dan warung.

ini. Pada kegiatan sosialiasi disampaikan

4. Mitra tidak melakukan pencatatan informasi-informasi mengenai latar pendapatan dan pengeluaran, sehingga belakang, target, sasaran dan tujuan seringkali keuntungan yang diperoleh kegiatan. Indikator-indikator tersebut tidak diketahui secara pasti. memiliki satu tujuan prinsip, yaitu

5. Pemasaran produk masih minim keberlanjutan dalam pengembangan fasilitas dikarenakan tidak adanya label kemasan sarana dan prasarana produksi serta produk sehingga masyarakat tidak peningkatan produksi UKM. Disamping itu mengetahui informasi mengenai tempat pelaksana kegiatan menyampaikan jadwal produksi mitra. kegiatan pengabdian yang akan dilakukan.

METODE PELAKSANAAN KEGIATAN

Metode yang digunakan dalam pelaskanaan kegiatan adalah sosialisasi, pelatihan dan pendampingan. Rancangan kegiatan dimulai dari sosialisasi kegiatan; pemberian bantuan alat penunjang produksi berupa kompor dan mesin penggiling;

pembuatan label kemasan yang eye catching dan pelatihan pengemasan; pelatihan

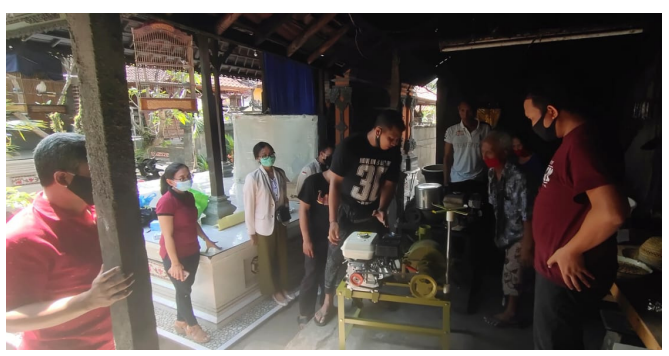

Gambar 4 Proses Sosialisasi Tim dengan Mitra Kegiatan

\section{Penyerahan Bantuan Alat Produksi}

Sesuai dengan tahapan pelaksanaan manajemen keuangan berupa pelatihan yang dilakukan, untuk menunjang dan pencatatan transaksi dan buku kas; meningkatkan proses produksi usaha pembuatan media pemasaran online berupa diberikan bantuan beberapa peralatan facebook dan Instagram serta pelatihan produksi. Peralatan produksi ini dapat penggunaan media pemasaran online; digunakan mitra untuk mempercepat evaluasi kegiatan.

\section{HASIL DAN PEMBAHASAN}

Kegiatan yang dilakukan pada pengabdian masyarakat ini dapat dijelaskan sebagai berikut.

\section{Sosialisasi Kegiatan}

Sosialisasi pada usaha Tahu itu pada tanggal 24 April 2020 dilakukan dilaksanakan pada Tanggal 17 April 2020. penyerahan alat produksi di lokasi mitra. Materi sosialiasi diberikan oleh Wayan Adapun bantuan yang diberikan kepada Hesadijaya Utthavi selaku ketua pelaksana. mitra adalah sebagai berikut : 
1. Mesin penggiling kedelai untuk menggiling kedelai kering

2. Kompor untuk memasak adonan tahu

3. Alat penyaring untuk menyaring tahu

4. Kemasan mika untuk pengemasan produk.

Berikut ini beberapa dokumentasi pada saat penyerahan bantuan alat produksi pada mitra dapat dilihat pada Gambar 6 .

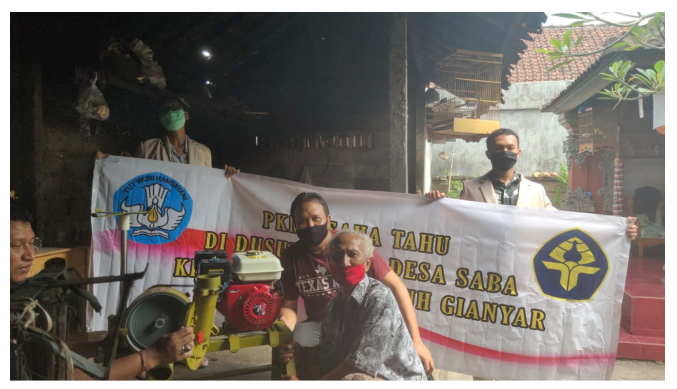

Gambar 5 Penyerahan alat produksi pada usaha tahu

Kegiatan penyerahan barang diikuti dengan pelatihan penggunaan peralatan produksi modern. Pelaksanaan kegiatan ini dilakukan sebagai penunjang keberlangsungan operasional usaha.

\section{Pelatihan Desain dan Labeling Kemasan Produk}

Untuk membuat produk lebih menarik serta dikenal oleh masyarakat, diperlukan label kemasan untuk produk tahu. Pada saat mitra hanya menggunakan plastik kiloan untuk membungkus tahu dan tidak disertai dengan label. Dengan adanya pengemasan mika dan label kemasan akan dapat meningkatkan value dari produk. Label produk yang didesain akan memuat informasi mengenai nama usaha. Desain labeling produk usaha tahu dapat dilihat pada Gambar 7.

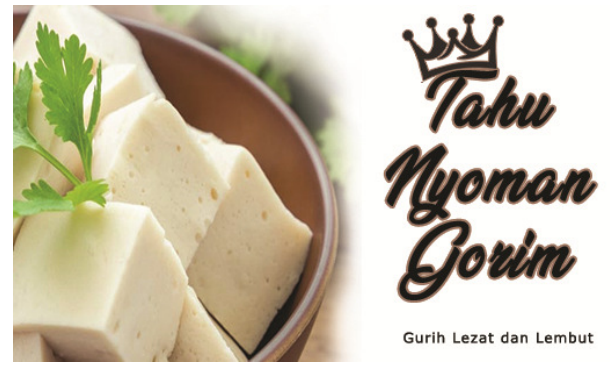

Gambar 6 Desain labeling kemasan tahu

Tahapan selanjutnya dilakukan pelatihan pengemasan produk menggunakan kemasan mika dan label kemasan stiker. Selain itu pada stiker label kemasan produk diberikan expired date agar konsumen dapat mengetahui tanggal konsumsi produk tahu. Produk yang telah dikemas dapat dilihat pada Gambar 8.

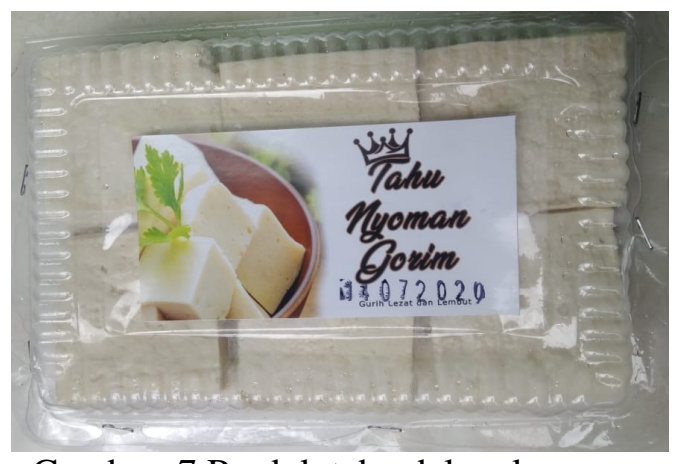

Gambar 7 Produk tahu dalam kemasan

\section{Pelatihan Manajemen Keuangan}

Manajemen keuangan sangat diperlukan dalam pengelolaan usaha. Laporan keuangan yang baik merupakan laporan yang lengkap dimulai dari pencatatan transaksi yang ada sampai dengan laporan keuangan yang dihasilkan [9]. Pelatihan manajemen keuangan sederhana dilakukan agar mitra mempunyai pengetahuan mengenai pengelolaan finansial yang lebih baik. Dengan adanya pelatihan ini diharapkan mitra dapat melakukan pencatatan order, mencatat setiap pengeluaran dan pemasukan usaha serta dapat mengetahui kondisi laba 
rugi dari usaha mereka. Pelatihan sosial yang sudah umum dan banyak manajemen keuangan yang akan dilakukan digunakan yaitu media sosial facebook dan adalah pelatihan pencatatan order maupun instagram. Instagram berdampak positif pada transaksi penjualan pada nota serta penjualan produk [11]. Pada pelatihan pencatatan buku kas sederhana. diperkenalkan mengenai cara penggunaan Dokumentasi kegiatan pelatihan manajemen media sosial serta cara mempromosikan keuangan dapat dilihat pada Gambar 9.

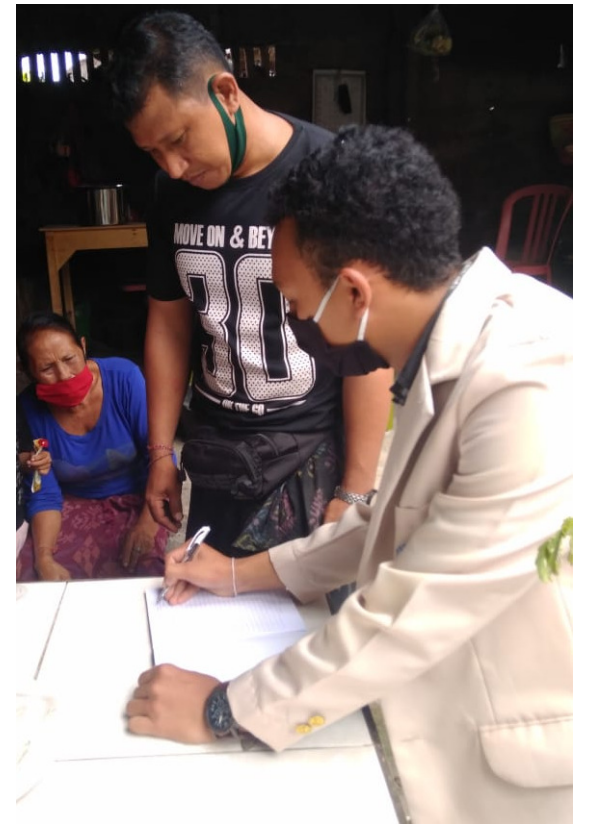

Gambar 8 Pelatihan manajemen keuangan sederhana

\section{Pembuatan dan Pelatihan Media Pemasaran Online}

Pemasaran merupakan aspek penting dalam pengelolaan usaha. Pemasaran dapat diartikan mengelola hubungan dengan pelanggan [10]. Mitra saat ini masih kesulitan dalam melakukan pemasaran produk. Pemasaran produk mitra masih bersifat konvensional dari mulut ke mulut ataupun dengan berjualan di pasar. Untuk mengatasi hal tersebut dan dengan kemajuan teknologi informasi maka pemasaran mitra dilakukan menggunakan media online yaitu media sosial. Media sosial yang digunakan sebagai media pemasaran adalah media produk pada media sosial. Dokumentasi kegiatan dapat dilihat pada Gambar 10.

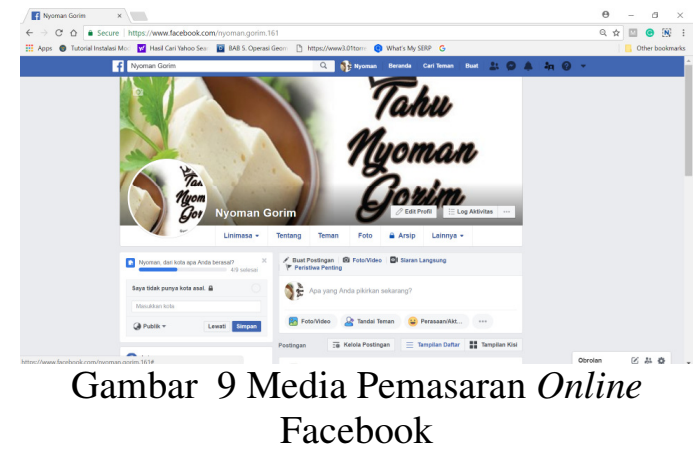

\section{Monitoring dan Evaluasi Kegiatan}

a. Monitoring dan Evaluasi Kegiatan Tahap I

Setelah pelaksanaan kegiatan dilakukan, maka langkah selanjutnya adalah melakukan evaluasi oleh ketua dan anggota pengabdian masyarakat. Evaluasi tahap I dilakukan untuk membandingkan perencanaan program dengan pelaksanaan program. Pelaksanaan kegiatan pengabdian masyarakat tentang pengembangan usaha tahu terlaksana sesuai dengan rencana, sesuai hasil kesepakatan pada saat sosialisasi dan pelatihan serta alat penunjang produksi. Berdasarkan hasil wawancara dengan mitra pada monitoring dan evaluasi tahap I ini terdapat peningkatan jumlah produksi dengan adanya bantuan peralatan produksi.

b. Monitoring dan Evaluasi Kegiatan
Tahap II
Monitoring dan evaluasi tahap II
dilakukan setelah seluruh kegiatan


terlaksana. Kegiatan ini dilakukan untuk dikemas untuk meningkatkan value atau nilai mengetahui ketercapaian pelaksanaan jual. Untuk kegiatan penggunaan sistem kegiatan dan target yang telah ditentukan keuangan untuk manajemen keuangan usaha, berdasarkan indikator capaian. Pada tahap berdasarkan hasil evaluasi terdapat 1 orang ini dilakukan evaluasi terhadap keseluruhan anggota yang dapat melakukan pencatatan kegiatan yang telah dilaksanakan. luaran keuangan. Sedangkan untuk kegiatan kegiatan dari pelaksanaan pengabdian penggunaan media pemasaran online, masyarakat yang telah dilakukan pengukuran terdapat 2 orang anggota usaha yang dapat pada saat evaluasi ditunjukkan oleh Tabel 1. menggunakan facebook dan Instagram

Berdasarkan Tabel 1 dapat dilihat bahwa sebagai media pemasaran online. Dapat adanya peningkatan alat produksi berdampak disimpulkan bahwa keseluruhan kegiatan pada peningkatan jumlah produksi sebanyak yang dilaksanakan telah sesuai dengan target $60 \%$. Selain itu, dengan adanya kemasan dan yang direncanakan.

label kemasan baru, $50 \%$ produk telah

Tabel 1. Pencapaian luaran kegiatan

\begin{tabular}{|l|l|l|l|}
\hline No & Kegiatan & Indikator capaian & Pencapaian \\
\hline 1 & $\begin{array}{l}\text { Peningkatan alat } \\
\text { produksi }\end{array}$ & $\begin{array}{l}\text { Meningkatnya 50\% kuantitas } \\
\text { produk }\end{array}$ & $\begin{array}{l}\text { Peningkatan jumlah } \\
\text { produksi sebanyak 60\% }\end{array}$ \\
\hline 2 & $\begin{array}{l}\text { Pengemasan dengan } \\
\text { kemasan dan label }\end{array}$ & $\begin{array}{l}50 \% \text { produk dikemas dengan } \\
\text { melibatkan 2 karyawan }\end{array}$ & $\begin{array}{l}50 \% \text { produk dikemas } \\
\text { dengan melibatkan 2 } \\
\text { karyawan }\end{array}$ \\
\hline 3 & $\begin{array}{l}\text { Penggunaan sistem } \\
\text { keuangan untuk } \\
\text { manajemen keuangan }\end{array}$ & $\begin{array}{l}\text { 1 orang anggota UKM dapat } \\
\text { membuat manajemen } \\
\text { keuangan sederhana }\end{array}$ & $\begin{array}{l}\text { 1 orang anggota dapat } \\
\text { melakukan pembuatan } \\
\text { buku kas }\end{array}$ \\
\hline 4 & $\begin{array}{l}\text { Penggunaan media } \\
\text { pemasaran } \text { online }\end{array}$ & $\begin{array}{l}\text { 1 orang anggota usaha dapat } \\
\text { menggunakan media sosial } \\
\text { untuk memasarkan produk }\end{array}$ & $\begin{array}{l}\text { 2 orang anggota usaha } \\
\text { dapat menggunakan media } \\
\text { sosial untuk memasarkan } \\
\text { produk }\end{array}$ \\
\hline
\end{tabular}

\section{KESIMPULAN}

Berdasarkan kegiatan yang telah dilakukan, bantuan alat produksi melengkapi keterbatasan alat yang menjadi permasalahan mitra sehingga dapat mempercepat waktu produksi dan meningkatkan jumlah produksi. Berdasarkan hasil evaluasi didapatkan bahwa adanya peningkatan jumlah produksi sebanyak 60\%, adanya peningkatan pengetahuan mitra mengenai pencatatan keuangan dan pemasaran menggunakan media online, terciptanya produk tahu yang lebih ekslusif dengan kemasan dan label kemasan yang baru.

\section{SARAN}

Adapun saran sebagai keberlanjutan program ini adalah mitra menerapkan hasil pelatihan yang telah diberikan sehingga usaha mitra mengalami perkembangan yang optimal. 


\section{UCAPAN TERIMAKASIH}

Terima kasih kepada Kementerian

Pendidikan dan Kebudayaan dan Politeknik

Negeri Bali yang telah memberikan

kesempatan kepada kami untuk

mendapatkan bantuan pendanaan kegiatan

Pengabdian kepada Masyarakat ini. Terima

kasih pula kepada mitra kegiatan atas Kerjasama dan antusiasnya selama

pelaksanaan kegiatan.

\section{REFERENSI}

[1] Yuliarti, N.C., Budiono. 2019. Sosialisasi Peningkatan Usaha Tahu Pada UD. Tagor Gebang Jember. Jurnal Pengabdian Masyarakat Ipteks. 5(1): 59-65.

[2] Bintoro, P.A., Maselia, P., Kintoko, A.M., Defanda, A.A., Fitriyanti, A., Ramadhan, F., Kartika, M., Septiani, U.A., Elvionita, D. 2017. Pembuatan Tahu Rumahan Khas Ledok Kulon. Jurnal Pemberdayaan. 1(2): 245-252.

[3] Sujianto, A.E. 2018. Pendidikan Kewirausahaan Melalui Pelatihan Produksi Tahu Dan Kerupuk Okara Bagi Ibu Rumah Tangga Desa Bendiljati Kulon Kabupaten Tulungagung. J-ADIMAS (Jurnal Pengabdian kepada Masyarakat). 6(1): $27-34$

[4] Aziz, A., Nurrohim, A. 2019. Pengembangan Usaha Tahu Pelaku Usaha Kecil Dan Menengah Di Kelurahan Krukut, Limo Depok. Seminar Hasil Pengabdian kepada
Masyarakat (Sabdamas). 26 - 27 September 2019, Jakarta, Indonesia, Hal 53-57.

[5] Prastyo, F.A.D. 2020. Perbaikan Mutu Produksi Tahu Pada Home Industri Mekar Sari Di Desa Babadan-Patianrowo -Nganjuk. Jurnal Valtech (Jurnal Mahasiswa Teknik Industri). 3(1):34 - 39.

[6] Rhohman, F., Budiretnani, D.A. 2018. Optimalisasi Proses Produksi Tahu untuk Peningkatan Kesejahteraan Produsen Tahu. Jurnal Panrita Abdi, 2018. 2(2): 113-118.

[7] Kasih , Y., Widagdo, H., Pratiwi, R. 2017. Pemberdayaan Pelaku Usaha Tahu Rumahan Di Kabupaten Banyuasin Sumatera Selatan. Seminar Nasional Pengabdian Kepada Masyarakat. 28 Agustus 2017, Palembang, Indonesia, Hal 309-321.

[8] Arifin, A., Tusholihah, M., Sanubari, S., Mardi, R. Perancangan Laporan Keuangan Berbasis Online Dalam Rangka Peningkatan Usaha Tahu Goreng Di Wilayah Sumedang Jawa Barat. Fairvalue: Jurnal Ilmiah Akuntansi Dan Keuangan. 1(2): 209222.

[9] Rostwentivaivi , V., Fizriani, A. 2019. Kelayakan Bisnis Dan Pemasaran Tahu Jojoh Di Kecamatan Karangpawitan, Kabupaten Garut. Jurnal Dedikasi Masyarakat. 3 (1): $59-67$.

[10] Indika, D.R., Jovita, C. 2017. Media Sosial Instagram Sebagai Sarana Promosi Untuk Meningkatkan Minat Beli Konsumen, Jurnal Bisnis Terapan, 1(1): 25-32 